\title{
What Controls Bedrock Shore Platform Hardness? A Field Study from South Africa
}

\author{
Authors: Knight, Jasper, and Burningham, Helene \\ Source: Journal of Coastal Research, 95(sp1) : 537-541 \\ Published By: Coastal Education and Research Foundation \\ URL: https://doi.org/10.2112/SI95-104.1
}

BioOne Complete (complete.BioOne.org) is a full-text database of 200 subscribed and open-access titles in the biological, ecological, and environmental sciences published by nonprofit societies, associations, museums, institutions, and presses.

Your use of this PDF, the BioOne Complete website, and all posted and associated content indicates your acceptance of BioOne's Terms of Use, available at www.bioone.org/terms-of-use.

Usage of BioOne Complete content is strictly limited to personal, educational, and non - commercial use. Commercial inquiries or rights and permissions requests should be directed to the individual publisher as copyright holder.

BioOne sees sustainable scholarly publishing as an inherently collaborative enterprise connecting authors, nonprofit publishers, academic institutions, research libraries, and research funders in the common goal of maximizing access to critical research. 


\title{
What Controls Bedrock Shore Platform Hardness? A Field Study from South Africa
}

\author{
Jasper Knight ${ }^{\dagger *}$ and Helene Burningham ${ }^{\star \S}$ \\ †School of Geography, Archaeology and \\ Environmental Studies \\ University of the Witwatersrand \\ Johannesburg, South Africa
}

*Department of Geography
University College London (UCL)
London, UK

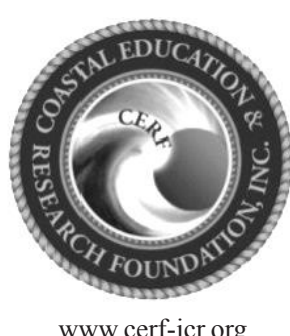

www.cerf-jcr.org

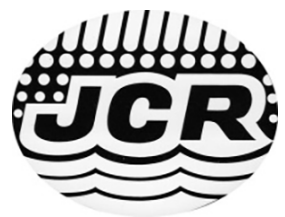

www.JCRonline.org

\begin{abstract}
Knight, J. and Burningham, H., 2020. What controls bedrock shore platform hardness? A field study from South Africa. In: Malvárez, G. and Navas, F. (eds.), Global Coastal Issues of 2020. Journal of Coastal Research, Special Issue No. 95, pp. 537-541. Coconut Creek (Florida), ISSN 0749-0208.

Bedrock shore platforms are common features along the Indian Ocean coast of South Africa but their properties and controls have not been well reported. This study presents high-resolution evidence for rock surface properties and hardness values from a sandstone platform at Morgan's Bay (Eastern Cape, South Africa) where the relative roles of environmental versus lithological factors on bedrock surface hardness can be evaluated. Results show that there is very little correspondence between rock hardness and either absolute platform elevation or distance from low water position of sea level. Two contrasting conceptual models are proposed to explain these results. One model proposes that a uniform geological control dominates, despite variations in environmental forcing. The alternative model considers that environmental controls such as waves and subaerial weathering do not significantly vary over the platform, despite any differences in platform relief and microenvironment. These different models can be used as testable hypotheses to evaluate the relative controls on, and thus interpretations of, measurements of rock surface hardness on shore platforms.
\end{abstract}

ADDITIONAL INDEX WORDS: Rock surface hardness, rocky coast, South Africa, subaerial weathering, waves.

\section{INTRODUCTION}

The morphological properties and evolutionary development of rock shore platforms are controlled by a combination of wave, tide and subaerial weathering and erosion processes operating on hard rock substrates (Trenhaile, 2005; Kennedy et al., 2017). As such, it is the interplay between these different processes and the nature of any geological controls that determine resultant patterns of small-scale features on these platforms (Stephenson and Naylor, 2011a). An additional complication is that weathering and erosion processes vary substantially across rock platforms, strongly controlled by the extent of wave run-up inland, wetting/ drying cycles, and different coastal ecosystems and thus bioweathering found in these micro-environments. Several studies have examined in detail the specific erosion processes associated with waves (Trenhaile and Kanyaya, 2007; Pappalardo et al., 2017; Matsumoto et al., 2018) and tides (Trenhaile and Layzell, 1981; Trenhaile, 2003), and the locations on rock shore platforms where these processes are most dominant. From this, it can be inferred that different shore-parallel morphological zones should exist along rock platforms, differentiated according to the most dominant weathering and erosion processes operating in those zones. Such a zonal pattern has been identified along some rocky shorelines in South Africa (e.g. Knight and Burningham, 2019).

DOI: 10.2112/SI95-104.1 received 31 March 2019; accepted in revision 13 February 2020

*Corresponding author: jasper.knight@wits.ac.za

${ }^{\circ}$ Coastal Education and Research Foundation, Inc. 2020
Although much work has been done globally on the relative roles of waves, tides, weathering processes and lithological controls on shore platform properties (e.g., Chelli et al., 2010), in reality it is difficult to decouple these different controls at a site scale because they commonly result in similar geomorphic impacts. In addition, there are feedbacks between these controls that might variously amplify or suppress the development of shore platform features (Dickson et al., 2013).

A continuing question, therefore, is whether geological properties of the rock surface influence the development of shore platform features to such an extent that different weathering and erosion processes are unable to be meaningfully imprinted on this surface. A method by which this question can be addressed is through high-resolution spatial analysis of rock surface hardness. This is because hardness values reflect the balance between weathering (in situ disintegration leading to lower values) and erosion processes (removal of weaker surface material, leading to harder values) that are found in different zones of the rock surface (Knight and Burningham, 2019). If hardness values vary with elevation across the platform, this likely reflects differential weathering and erosion related to wave and tide action. However, if hardness values are similar irrespective of elevation, then geological controls are more important, negating the impacts of differential weathering and erosion. These end-member scenarios provide a testable hypothesis to objectively evaluate the role of geological versus environmental controls on shore platform properties. 
The aim of this study is to test this hypothesis using field data from a rocky shore platform at Morgan's Bay on the Indian Ocean coast of South Africa. In detail, this paper (1) outlines the lithological and climatic properties of the study site, (2) presents high-resolution rock surface hardness data measured using an Equotip instrument, and (3) uses these data to consider the relative roles of geological versus environmental controls on platform properties and dynamics.

\section{Study Area}

Morgan's Bay is located $50 \mathrm{~km}$ northeast of East London on the Eastern Cape of South Africa, facing the Indian Ocean (Figure 1). The bay lies at the mouth of a small river closed by a sandy coastal barrier, forming a small lagoon. Bedrock headlands lie adjacent to this sandy barrier and bedrock is exposed within the intertidal zone, forming an undulating and variable shore platform. Bedrock comprises north-dipping tabular sandstones of the Late Carboniferous-Middle Jurassic Karoo Supergroup (Johnson et al., 1996). Individual sandstone beds are $\sim 40 \mathrm{~cm}$ thick and dip $\sim 20^{\circ}$ to the north.

This coastal stretch is high microtidal (mean spring tidal range at East London of $1.59 \mathrm{~m}$ ) and experiences moderate offshore wave heights generated by Southern Ocean swells from the south or south-southeast (Corbella and Stretch, 2012). Wave run up can be significant here, reaching well into the inhabited hinterland during storm conditions (Dixon et al., 2015). These different geological and environmental forcings have influenced coastal dynamics, including the seasonal and interannual distributions of surficial sand, which is found in particular at the back of the platform and within the runnels between the undulating bedrock highs (Figure 1b). Dixon et al. (2015) examined storm swash terraces developed in backshore sand and gravel at this Morgan's Bay site. This previous study was concerned solely with interbedded sands and gravels at the back of the platform and did not describe the platform itself.

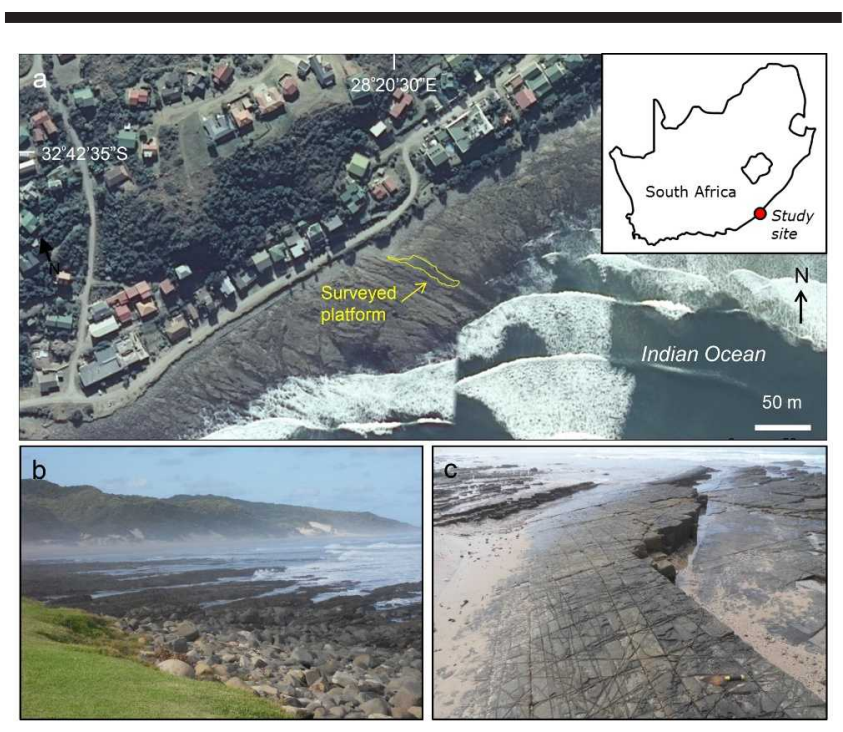

Figure 1. Location of Morgan's Bay, South Africa: (a) Location of the surveyed platform within Morgan's Bay (background image: NGI, dated 10 August 2017), (b) view to the northeast across the bay, showing the disposition of bedrock outcrops in the upper beach, (c) view of the surveyed platform looking seaward (trowel in foreground for scale).

\section{METHODS}

Because of the stepped nature of the platform imparted by the north-dipping sedimentary beds, bedding plane surfaces dip more shallowly to the north than the exposed face of the sandstone bed which is subvertical and dipping broadly south (Figure 1b, c). One dipping bedding plane surface ( $45 \mathrm{~m}$ long in a seaward direction, $6 \mathrm{~m}$ wide in a cross-shore direction) was selected for survey. The upper intertidal surface was topographically mapped using a differential GPS (dGPS, vertical and horizontal accuracy of $\pm 3 \mathrm{~cm}$ ). Over 1200 topographic readings were recorded. These data were processed and interpolated onto a regular grid $(10 \times 10 \mathrm{~cm}$ cell size) to generate a digital elevation model (DEM). Weathering and erosion features were recorded in the field. Across the surveyed surface, an Equotip instrument was used to measure rock surface hardness. The Equotip was chosen over the more commonly used Schmidt hammer because it has advantages in sampling softer rocks such as sandstone as it is less destructive (Mol, 2014), and has been used successfully to measure rock surface hardness on stratigraphically-equivalent sandstones elsewhere in South Africa (Mol and Viles, 2012). The sampling strategy undertaken for rock surface hardness focused on dry and upstanding surfaces of the case-hardened sandstone platform, and measurements were undertaken at low tide during fine weather. Measurements could not extend into the lower intertidal zone as this was frequently rewetted by wave splash and run up, even during spring low tides. Previous studies have shown that Equotip measurements are sensitive to rock moisture (Viles et al., 2011), which may be an issue on rock platforms subject to wave-splash. In total, 82 locations were sampled with the Equotip from across the surveyed platform, with 20-25 valid readings per location (total of 1989 individual readings). The positions of all sampled locations were noted with the dGPS. These data were then statistically evaluated for spatial variations in rock surface hardness relative to elevational position within the tidal frame, and distance landward of low tide position.

\section{RESULTS}

\section{Lithological and Geomorphic Features}

Platform morphology is shown in Figure 2. Here, intersecting and vertical conjugate fractures impart lines of weakness to the rock surface. Analysis of digital photos of the rock platform surface shows that bedrock fracture density ranges from 1.3 to $5 \%$ (mean $2.79 \%, 1 \sigma$ range $0.78, \mathrm{n}=33$ ). The surface of the dipping platform, corresponding to a bedding plane surface, is case-hardened to a depth of several $\mathrm{cm}$. Internal bedding planes, which are not case-hardened, are significantly different in terms of their texture and micromorphology when exposed by erosion (Figure 2b). These internal surfaces were not sampled by the Equotip. The stepped alongshore profile of the sandstone beds is developed where vertical fractures create a sharp step 25 to $40 \mathrm{~cm}$ high located on the south-facing side of the platform (Figures 1c, 2c, d). DEM mapping of the platform clearly reflects the dipping platform surface (Figure 3). Small-scale (few $\mathrm{cm}$ in diameter) depressions are present on both vertical and horizontal rock faces. Horizontal surfaces of the rock platform show circular depressions that are usually water-filled from wave spray and may contain loose sand or small shells (Figures 2a, 3a). Cavernous weathering features (tafoni) are present on vertical rock faces, are larger than on horizontal faces, and tend to have an elongate outline in plan view and with depressions that are several $\mathrm{cm}$ in depth and 


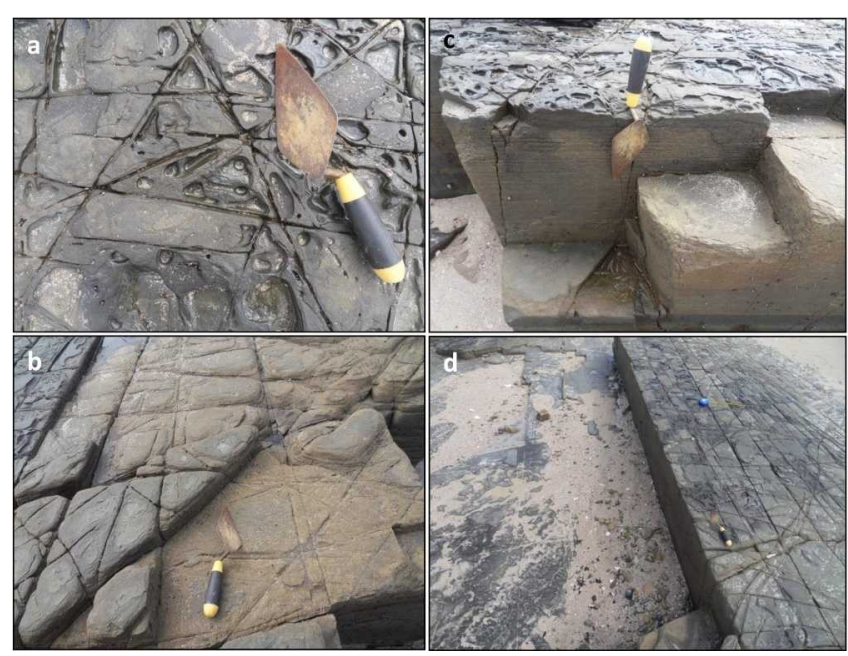

Figure 2. Photos of the rock surface at Morgan's Bay: (a) Intersecting fractures, (b) fractures exploited by differential erosion, (c) boulder plucking at the steep platform face, directed along joints and bedding planes, (d) platform step morphology controlled by fracture alignment, with surficial sand accumulating at the bottom of the step. Trowel is 22 cm long.

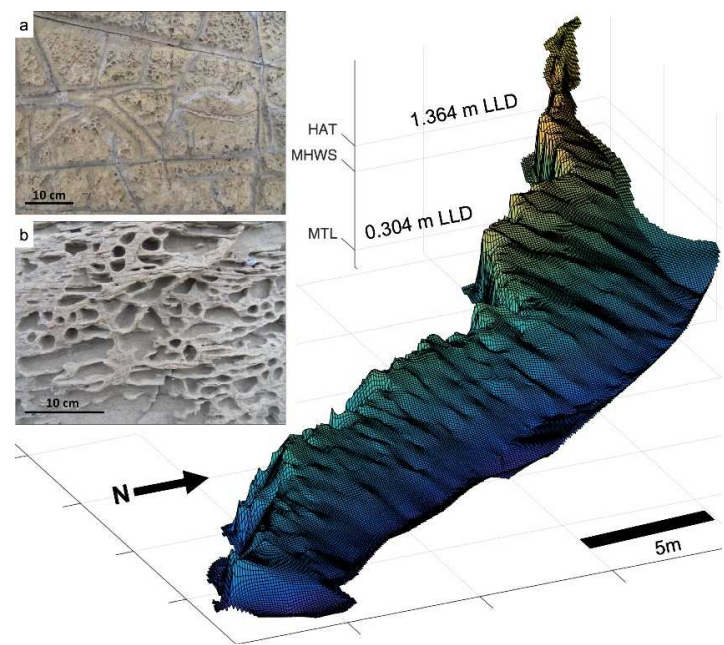

Figure 3. Digital elevation model of the surveyed platform surface. $\mathrm{MTL}=$ mean tide level, MHWS=mean high water springs, HAT=highest astronomical tide, $\mathrm{LLD}=$ land levelling datum. Inset showing (a) horizontal and (b) vertical rock surface weathering features.

sometimes with overturned rims (Figure 3b). Tafoni are observed in particular in the upper intertidal part of the platform but there is no clear distinction by elevation. Analysis of surficial sediment from the thin drape adjacent to the surveyed platform (Figures 1c, 2d) shows a $\mathrm{D}_{50}$ grain size of $425 \mu \mathrm{m}, \mathrm{CaCO}_{3}$ content of $33.6 \%(\mathrm{n}=4)$ and moderate sorting. Aerial imagery suggests that the backshore sand drape is temporally and spatially variable; the upper parts of the platform can be completely covered or exposed month to month, year to year.

\section{Rock Surface Hardness}

Equotip summary statistics plotted against elevation of the sample site and distance up the platform (Figure 4) show limited
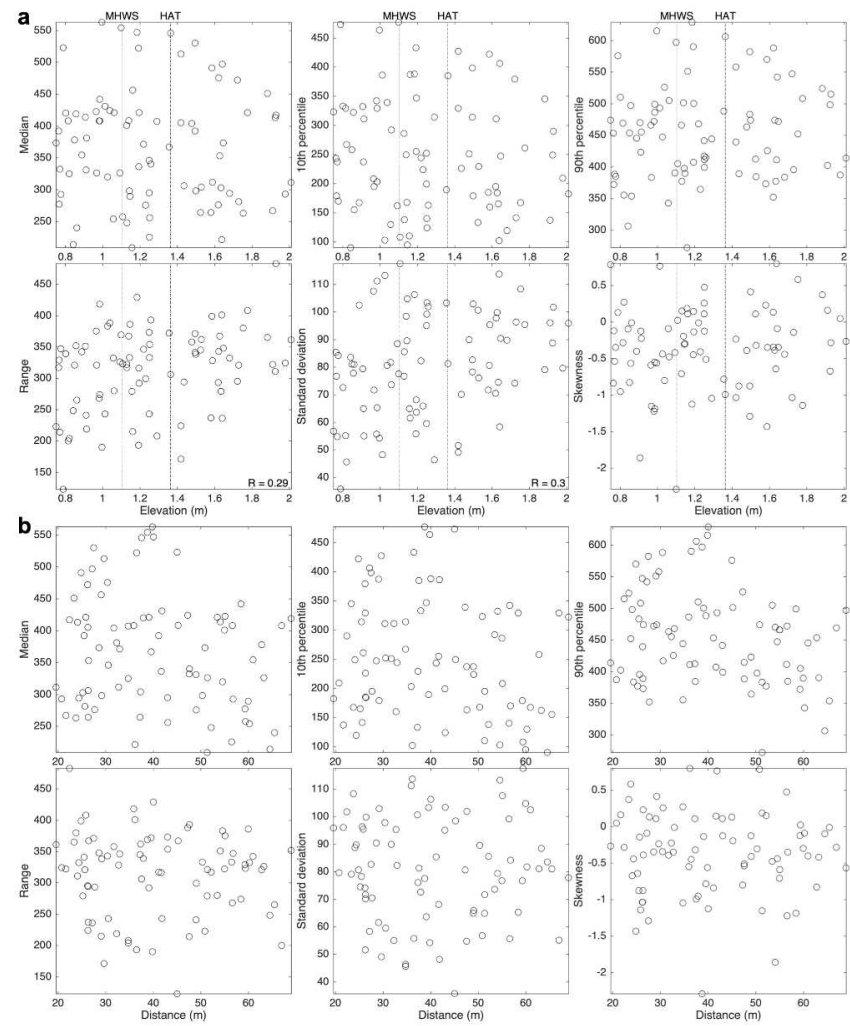

Figure 4. Scatter plots of descriptive statistics in Equotip values relative to (a) elevation and (b) cross-shore distance from the hinterland.

correlations; at the $99 \%$ significance level, only Equotip range and standard deviation are correlated (positively) with elevation ( $\mathrm{R}=0.29$ and $\mathrm{R}=0.30$, respectively). There is a wide distribution of rock surface hardness values at each site and over the platform, with only a small suggestion of decreasing upper extremes $\left(90^{\text {th }}\right.$ percentile) with distance seaward. The associations between location and Equotip statistics are weak, but when the raw Equotip data are grouped into elevation $(<$ MHWS, HAT to MHWS, and $>$ HAT $)$ and distance classes $(<30 \mathrm{~m}, 30$ to $50 \mathrm{~m}$, and $>50 \mathrm{~m}$ from the hinterland vegetation), the associations with elevation are less evident, but more significant cross-shore patterns in hardness values emerge (Figure 5). Substantive differences in hardness values are identified according to distance; a Kruskal Wallis test reveals significant differences between seaward $(>50 \mathrm{~m})$ and more landward classes $(\mathrm{p}<0.01)$, but not between the two landward classes.

Thus, although the correlations across the Equotip descriptive statistics suggest stronger associations with elevation (Figure 4a), the raw data populations show more distinct differences crossshore. Combining distance and elevation classes affords a more integrated evaluation of these patterns (Figure 5a, b). Here, there are strong differences between the $3 \mathrm{D}$ zones defined, which show that both horizontal and vertical position play a role in surface hardness. Cross-shore, there is an overall decline in hardness from landward to seaward, but in each distance class, hardness is higher at lower elevations than higher areas (Figure 5a). When the classes are ordered by elevation (Figure $5 b$ ), no overarching trend is evident, but within each elevation class, the cross-shore decline in hardness is clear. 


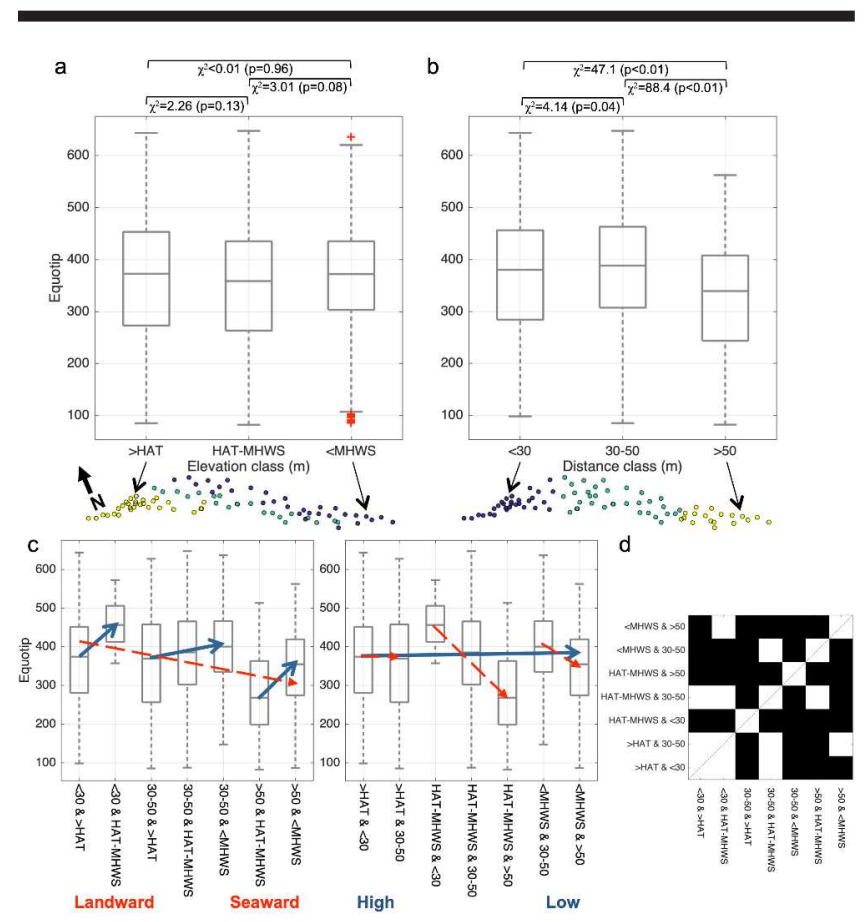

Figure 5. Comparative boxplots of Equotip values showing (a) elevation, and (b) distance classes, (c) 3D position classes, organized by distance (left) and elevation (right) with relative trends in hardness across these gradients shown, and (d) p-value matrix showing significant differences between $3 \mathrm{D}$ classes. Abbreviations according to Fig. 3.

\section{DISCUSSION}

The rock platform at Morgan's Bay exhibits many of the typical features found on such platforms worldwide, including abraded and planar surfaces, large depressions formed by the plucking by waves of angular boulders from the rock surface, and the presence of tafoni (e.g., Andriani and Walsh, 2007; Chelli et al., 2010). However, here a geological structural control on platform geomorphology is evident, in the form of a stepped longshore platform profile and north-dipping bedding plane surface, which allows lower elevations to penetrate further landward than would otherwise occur. It is notable that wave erosion has not cleanly planated the bedrock along strike, as is found along other rock coasts (e.g., Andriani and Walsh, 2007; Blanco-Chao et al., 2007). The sandstone bedrock at Morgan's Bay has relatively high fracture density, which can potentially be exploited by wave action, causing the detachment and transport of bedrock blocks (e.g., Stephenson and Naylor, 2011b). Evidence for block detachment is shown by the angular depressions (sockets) on the platform outer edge (Figure 2b, c). Boulders were only observed at the back of the beach (Figure 1b), not on the platform surface itself, but Dixon et al. (2015) have reported storm wave transport of boulders here. The water-filled depressions on the platform surface, supplied by wave-splash, are potentially affected by bioerosion by molluscs and gastropods where there is preferential water availability during low tide (Pappalardo et al., 2018) (Figures 2, 3). Tafoni, developed on vertical faces, are formed by salt and wetting/drying weathering (McGreevy, 1985). These microscale landforms have not been commonly discussed from South African rocky coasts (Knight and Grab, 2015) although they are identified on sandstones inland (Grab et al., 2011; Mol and Viles, 2012).

Statistically significant patterns of surface hardness are evident with respect to distance and elevation, but most notable patterns are shown when defining 3D zones (Figures 4, 5c). The dominant cross-shore trend is of decreasing hardness in a seaward direction, and superimposed on this is a trend of increasing hardness with decreasing elevation. The 3D zone class with the lowest hardness is seaward but on the higher parts of the ridge only; hardness then increases downslope, following the dipping platform surface. Maximum hardness is found on the landward part within the high intertidal zone (MHWS-HAT). These results are somewhat paradoxical - lower hardness seaward, but within this, greater hardness at lower elevations - which explains why strong trends are not evident within a clear spatial pattern. This is intrinsically linked to the structural geology of the platform. Inkpen et al. (2010) showed that erosion rates increase landwards up a platform surface, consistent with the landward increase in hardness at the site examined here, but this reflects a mix of erosional and subaerial weathering processes that combine to maximize downwearing. For this to generate harder surfaces, this must also be associated with efficient removal of weathered and eroded material, and in low relief environments such as shore platforms, this requires waves. Wave processes have been considered as geomorphically significant on the South African coast, with high swell waves from the Southern Ocean (Smith et al., 2010; Salzmann and Green, 2012). Evidence for wave plucking, by block removal from the platform surface and lateral step, is observed at this site (Figure 2b), but perhaps more important here is the path of runup. Although stepped subtidal platforms influence wave erosion patterns (Kennedy, 2016), it is likely that similar structures within the intertidal zone will also modify wave processes; wave runup can move efficiently up the platform ramp, whilst backwash is then channeled seawards through the lower elevation channel at the base of the step. For each cross-shore location, increased channeling of backwash at the base of the ramp is likely more effective in removing weathered and eroded material, leading to harder surfaces.

The higher Equotip values can also be explained in relation to case-hardened platform surfaces. This is laterally extensive and has, visually, helped maintain the integrity of the platform (high cross-shore topographic relief rather than wave planation) (Figure 1b, c). Case-hardening of bedding plane surfaces can also influence the development of tafoni by stabilizing the rock surface and allowing for subsurface detachment of mineral grains, enhanced by microclimate effects within the tafoni depression (Dorn et al., 2017).

\section{CONCLUSIONS}

This study examines the different factors contributing to rock surface hardness on a sandstone shore platform in South Africa where case-hardening has increased the strength of the rock surface, but where erosive energy from waves and tides is also high. Results indicate a complex multidimensional relationship between bedrock surface hardness cross-shore and vertically, relative to the tidal frame. This potentially limits the use of surface hardness as a proxy of either of these variables. Instead, an integrated analysis based on both elevation (tides) and distance (extent of wave inundation) shows that elevation range and standard deviation in particular are statistically important, but 
that distance in a cross-shore direction results in clearer spatial patterns of hardness values. These results are significant when it comes to evaluating wider controls on rocky shore platform dynamics and weathering/erosion rates.

\section{LITERATURE CITED}

Andriani, G.F. and Walsh, N., 2007. Rocky coast geomorphology and erosional processes: A case study along the Murgia coastline South of Bari, Apulia - SE Italy. Geomorphology, 87, 224-238.

Blanco-Chao, R.; Pérez-Alberti, A.; Trenhaile, A.S.; Costa-Casais, M., and Valcárcel-Díaz, M., 2007. Shore platform abrasion in a para-periglacial environment, Galicia, northwestern Spain. Geomorphology, 83, 136-151.

Chelli, A.; Pappalardo, M.; Llopis, I.A., and Federici, P.R., 2010. The relative influence of lithology and weathering in shaping shore platforms along the coastline of the Gulf of La Spezia (NW Italy) as revealed by rock strength. Geomorphology, 118, 93-104.

Corbella, S. and Stretch, D.D., 2012. The wave climate on the KwaZulu-Natal coast of South Africa. South African Institute of Civil Engineers, 54, 45-54.

Dickson, M.E.; Ogawa, H.; Kench, P.S., and Hutchinson, A., 2013. Sea-cliff retreat and shore platform widening: steadystate equilibrium? Earth Surface Processes and Landforms, 38, 1046-1048.

Dixon, S.; Green, A., and Cooper, A., 2015. Storm swash deposition on an embayed rock coastline: facies, formative mechanisms, and preservation. Journal of Sedimentary Research, 85, 1155-1165.

Dorn, R.I.; Mahaney, W.C., and Krinsley, D.H., 2017. Case hardening: Turning weathering rinds into protective shells. Elements, 13, 165-169.

Grab, S.W.; Goudie, A.S.; Viles, H.A., and Webb, N., 2011. Sandstone geomorphology of the Golden Gate Highlands National Park, South Africa, in a global context. Koedoe, 53, 985, doi:10.4102/koedoe.v53i1.985.

Herterich, J.G.; Cox, R., and Dias, F., 2018. How does wave impact generate large boulders? Modelling hydraulic fracture of cliffs and shore platforms. Marine Geology, 399, 34-46.

Inkpen, R.J.; Stephenson, W.J.; Kirk, R.M.; Hemmingsen, M.A., and Hemmingsen, S.A., 2010. Analysis of relationships between micro-topography and short- and long-term erosion rates on shore platforms at Kaikoura Peninsula, South Island, New Zealand. Geomorphology, 121, 296-273.

Johnson, M.R.; van Vuuren, C.J.; Hegnberger, W.F.; Key, R., and Shoko, U., 1996. Stratigraphy of the Karoo Supergroup in southern Africa: an overview. Journal of African Earth Sciences, 23, 3-15.

Kennedy, D.M., 2016. The subtidal morphology of microtidal shore platforms and its implication for wave dynamics on rocky coasts. Geomorphology, 268, 146-158.

Kennedy, D.M.; Coombes, M.A., and Mottershead, D.N., 2017. The temporal and spatial scales of rocky coast geomorphology: a commentary. Earth Surface Processes and Landforms, 42, 1597-1600.

Knight, J. and Burningham, H., 2019. Bedrock hardness values and morphological zonation of a shore platform in South Africa. Transactions of the Royal Society of South Africa, in press.
Knight, J. and Grab, S.W. 2015. Rocky Shorelines of the Wild Coast. In: Grab, S.W. and Knight, J. (eds), Landforms and Landscapes of South Africa. Springer, Switzerland, pp. 55-61.

Matsumoto, H.; Dickson, M.E., and Kench, P.S., 2018. Modelling the relative dominance of wave erosion and weathering processes in shore platform development in micro- to megatidal settings. Earth Surface Processes and Landforms, 43, 2642-2653.

McGreevy, J.P., 1985. A preliminary scanning electron microscope study of honeycomb weathering of sandstone in a coastal environment. Earth Surface Processes and Landforms, 10, 509-518.

Mol, L., 2014. Measuring rock hardness in the field. In: Cook, S.J., Clarke, L.E. and Nield, J.M. (eds), Geomorphological Techniques (Online Edition). British Society for Geomorphology, London, 8pp.

Mol, L. and Viles, H.A., 2012. The role of rock surface hardness and internal moisture in tafoni development in sandstone. Earth Surface Processes and Landforms, 37, 301-314.

Pappalardo, M.; Cappietta, L.; Arozarena Llopis, I.; Chelli, A., and De Fabritiis, L., 2017. Development of shore platforms along the NW coast of Italy: The role of wind waves. Journal of Coastal Research, 33, 1102-1112.

Pappalardo, M.; Maggi, E.; Geppini, C., and Pannacciulli, F., 2018. Bioerosive and bioprotective role of barnacles on rocky shores. Science of the Total Environment, 619-620, 83-92.

Salzmann, L. and Green, A., 2012. Boulder emplacement on a tectonically stable, wave-dominated coastline, Mission Rocks, northern KwaZulu-Natal, South Africa. Marine Geology, 323, 95-106.

Smith, A.M.; Mather, A.A.; Bundy, S.C.; Cooper, J.A.G.; Guastella, L.A.; Ramsay, P.J., and Theron, A., 2010. Contrasting styles of well-driven coastal erosion: examples from KwaZuluNatal, South Africa. Geological Magazine, 147, 940-953.

Stephenson, W.J. and Naylor, L.A., 2011a. Within site geological contingency and its effect on rock coast erosion. Journal of Coastal Research, SI64, 831-835.

Stephenson, W.J. and Naylor, L.A., 2011b. Geological controls on boulder production in a rock coast setting: Insights from South Wales, UK. Marine Geology, 283, 12-24.

Trenhaile, A.S., 2003. Modeling the effect of tidal wetting and drying on shore platform development. Journal of Coastal Research, 20, 1049-1060.

Trenhaile, A.S., 2005. Modelling the effect of waves, weathering and beach development on shore platform development. Earth Surface Processes and Landforms, 30, 613-634.

Trenhaile, A.S. and Kanyaya, J.I., 2007. The role of wave erosion on sloping and horizontal shore platforms in macro- and mesotidal environments. Journal of Coastal Research, 23, 298-309.

Trenhaile, A.S. and Layzell, M.G.J., 1981. Shore platform morphology and the tidal duration factor. Transactions of the Institute of British Geographers NS, 6, 82-102.

Viles, H.; Goudie, A.; Grab, S., and Lalley, J., 2011. The use of the Schmidt Hammer and Equotip for rock hardness assessment in geomorphology and heritage science: a comparative analysis. Earth Surface Processes and Landforms, 36, 320 333. 